Article

\title{
A study on challenges and solutions for specialized English teaching and learning in the context of international integration.
}

\author{
Tuyet, Truong Thi Anh ${ }^{1 *}$
}

Citation: Tuyet, T. T. A. (2021, August 14). A study on challenges and solutions for specialized English teaching and learning in the context of international integration 2021,

August, 14.

https://doi.org/10.31235/osf.io/qhyr2

Academic Editor: Tuyet, Truong Thi Anh.

Received: 2021, August,12.

Accepted: 2021, August, 14.

Published: 2021, August, 14.

Publisher's Note: MDPI stays neutral with regard to jurisdictional claims in published maps and institutional affiliations.

Copyright: (c) 2021 by the authors. Submitted for possible open access publication under the terms and conditions of the Creative Commons Attribution (CC BY) license (https://creativecommons.org/license s/by/4.0/).
1 Ho Chi Minh city University of Food Industry; tuyety14@gmail.com

* Correspondence: tuyety14@gmail.com; Tel: +84 362702291

\begin{abstract}
The country is increasingly developing, actively integrating into the world economy in all aspects, the issue of teaching and learning English for Specific Purposes in the educational program in our country today, is very much appreciated by the state and society's care and attention. Many seminars and reforms have been organized and carried out at all levels of study on issues such as curriculum content, teaching methods innovation, retraining and improving the quality of teachers, equipment, etc. teaching materials, reforming testing methods, assessing and recognizing learners' qualifications in line with international standards. However, these efforts have not met the requirements of an increasingly dynamic and frequently changing society today. Therefore, the research paper titled "Challenges and solutions for teaching and learning English for Specific Purposes (ESP)" is a study to find out the difficulties and provide several reasonable solutions to overcome the situation in teaching and learning English majors in the context of international integration at Ho Chi Minh City University Of Food Industry (HUFI) as well as other universities. Thereby analyzing some situations and some challenges that specialized English teaching and learning are facing today, the author of the article proposes many possible solutions to achieve results according to the goals set out of the training institution. The lack of training and not meeting the current social needs has made specialized English training not as effective as expected and wasted money on public investment for this work. Effective, foreseeable, synchronous, and comprehensive learning solutions will partly help improve teaching and learning English for Specific Purposes in the context of international integration.
\end{abstract}

Keywords: Challenging, solutions, English for Specific Purposes, ESP, teaching, learning, HUFI, international integration.

\section{Introduction}

In the general trend of Teaching English as a Foreign Language (TEFL), many studies refer to English for Specific Purposes (ESP) as a division. Inseparable and plays an important role. If English for Specific Purposes is for learners and linguistically intensive use, specialized English is important to a broader and more diverse audience: students of all sciences other than languages. Therefore, English for Specific Purposes training institutions all wants to achieve large-scale training objectives in terms of quantity and quality standards, to meet the needs of a large training audience, and to create truly quality training products. In other words, trained staff must be able to use English for Specific Purposes in their work after graduation. However, the fact that English for Specific Purposes training in recent years has revealed difficulties and limitations in many aspects, leading to many training institutions not achieving desired goals.

\section{Literature review}




\subsection{Opportunities and obstacles in English for Specific Purposes:}

English for Specific Purposes (ESP) is a subject included in the language curriculum for university students in many countries around the world. English for Specific Purposes (ESP) is the term used to refer to the English used in professional work or to serve the work in different majors. Over the past few decades, there have been many studies on the English for Specific Purposes characterization or teaching methodology. Recent studies show that teaching and learning English for Specific Purposes is opening up many opportunities as well as facing challenges from many sides. Sharing many common views, different universities around the world that have ESP training (Hungary, Iran, Malaysia, Russia, Romania, Turkey, Italy, ...) all recognize that: while ESP provides learners with professional approaches through the use of English in work communication; or to find information to serve the job... Feed and feed teaching and learning still face several obstacles in program allocation, selection of the appropriate curriculum, entry-level, and learners' level of absorption. As well as the expertise and methods of the teachers... make this work not or not as expected. A study by Tar and associate (2009) on the lack of language proficiency found that today's Hungarian students are too indifferent, passive, lack interest in science, and not very interested in searching stuff additional knowledge. They do not learn much from English courses in university, leading to a lack of language proficiency is not formed or strengthened. Savas (2009) said that the main difficulty of this situation in Turkey was the lack of professional knowledge and training by teachers. In addition, Amirian and Tavakoli (2009) have also re-evaluated course programs on ESP in Iran, claiming that the design of the curriculum and the content structure of the curriculum was not completely consistent, Which is not going to motivate students' learning because they run the risk of thinking that ESP is a non-useful subject for their work (Tavakoli, 2009). In addition to these mechanical difficulties, Kaur and Clarke (2009) stated that the situation of office workers in Malaysia working in companies hadn't shown good English communication ability at work. So they need to be retrained in all four skills. Similarly, Savas (2009) states that Turkish students, after receiving ESP training, have very limited contributions to the economic, social, and educational development of the country as well as the locality where they work. Professional dynamics in using English is also a problem studied by Marginson and Burnie (2004). In addition, in a recent article, Bouzidi (2009) has a specific study on the lack of a link between learning ESP and actual working in the workplace as well as how to overcome obstacles. That force is equal to activities in the ESP classroom. From the above studies, it can be seen that besides the mechanical difficulties mentioned previously, the management of teaching and learning ESP for optimal efficiency has recently been questioned the most. People ask questions: "What is the reason why people who study ESP after graduation are unable to use it?" guys ask," what is training according to social needs?", "Do we have excess training or are we missing something?" or "Why do some civil servants still need English retraining for professional work while they have received formal training in university". To tackle the problem, the author take a look at the current state of ESP training at the University of Food Industry in Ho Chi Minh City.

\subsection{Current situation of English for Specific Purposes teaching and learning at HUFI:}

2.2.1. Regulations on programs and curriculum:

According to the detailed framework program on teaching basic English under the credit system prescribed by the Ministry of Education and Training, the basic English subject is taught in 120 hours (Theory: 42 hours; Practice, workshop Essay, homework: 72 hours; test and review: 6 hours). However, the popular textbooks chosen by universities across 
the country today are New Cutting Edge of Logman publisher or English Know-how of Oxford publisher. After completing the basic English section, students will continue with the ESP session. The curriculum and related factors are determined by the disciplines of each different school according to the training programs of those disciplines.

At the Ho Chi Minh City University Of Food, the specialized English period for students consists of 3-4 credits (theory) equivalent to $30-45$ periods. The textbooks are compiled by lecturers (teachers) of the Faculty of Foreign Languages for different subjects and approved by the Scientific Council. (Nghi, 2013)

In some other universities in Ho Chi Minh City: At the University of Foreign Languages and Informatics in Ho Chi Minh City, the English for Specific Purposes phase of students includes a full-course knowledge block greater than or equal to 141 credits, excluding the knowledge of physical education and physical education defense Education. The curriculum is compiled by lecturers (Teachers) of the Faculty of English Literature for 8 different majors and approved by the Faculty Council. At some other universities in Ho Chi Minh City, the distribution ratio of English for Specific Purposes units to the number of basic English curriculum units is usually 6/10, 8-9/10, or 10/16 (Banking University, Economics University, Open University, Ton Duc Thang Semi-Public University).

2.2.2. Teaching and learning English for Specific Purposes - The national picture:

Taking a look at the situation of teaching and learning English for Specific Purposes at many universities across the country, the general picture of the situation and challenges can be seen as follows:

\section{Training programs}

Currently, there is no uniform nationwide program for training English for Specific Purposes. The regulations of the Ministry of Education and Training on the number of teaching periods as well as the required number of study units to accumulate are also not consistent for each regional university or at a particular time. Basic English or Non-Special Foreign Languages may have clearer rules. Particularly, English for Specific Purposes has not been distributed in specific and consistent programs for all universities across the country, so it is difficult to have a common voice in training.

Teaching staff and teaching methods

Most of the young teachers assigned to teach English for Specific Purposes do not have much experienced in that specialty and terminology because they are not trained indepth but are mainly self-study. Others have strong knowledge of English for Specific Purposes, but the teaching method is not suitable.

The teaching method that most teachers apply is still influenced by the old curriculum and is not communicative. Teaching methods aimed at activating students' discovery, creativity, and real communication... seem to have only been tested but not yet widely applied.

The teaching staff is not stable. When young teachers are well-trained in their subject area, they tend to switch to specialized language teaching.

Students' sense of learning and receptivity level 
While the study time is short, the practice environment in the native language is not available, the students' awareness is not high, making the students' acquisition still limited.

There is a difference in the English proficiency of students in the first stage and the ESP stage as well as the difference in the level of many students in the same class, causing many difficulties for teachers.

Students of the natural and engineering majors often have a positive learning attitude and higher receptivity than the students of the social sector because they need to access the latest knowledge in the world of the social sector is not as urgent as in the case of social science engineering field.

Students who are not passionate about learning ESP, have a coping attitude mainly. Many students do not have a clear motivation to study, just hoping to get a score of five to avoid re-learning.

\section{Curriculum}

Some curricula that schools are using are outdated, not up-to-date, or inconsistent across institutions.

The structure of the textbooks is almost the same with most of the focus on the coursework, specialized vocabulary, reading comprehension, and translation. This structure inhibits the creativity of the teacher and the active learning of the students. Many classes are boring and not interested in such a curriculum.

\section{Check}

The subject, semester, entrance, and exit exams are still local and local, lacking a unified standard assessment tool such as international standard test questions such as TOEFL, TOEIC, etc. The assessment method is not highly reliable because it is the teachers themselves that teach and score the questions. There has been no continuity of assessment.

The training unit did not agree on the goal, did not find out the actual work needs of the employees using ESP.

There is no specific research on this issue so far. Other studies on ESP only focus on teaching and learning, with little research on the correlation between actual needs and training results. However, as reflected by some labor recruitment agencies in Ho Chi Minh City or Hanoi, the recruited employees only have basic English skills to communicate at work. As required, in addition, other specialized knowledge or related communication knowledge is still very weak, not meeting the working needs, requiring additional training or further training, even in the graduation transcript their ESP scores are quite high.

\subsection{The situation of teaching and learning specialized English at HUFI:}

In the same situation, teaching and learning English for Specific Purposes at HUFI universities also inevitably encounter certain difficulties like other universities. Through the practice of directly teaching and managing basic and specialized English teaching at HUFI combined with learning from classroom teachers at the Faculty of Specialized English - Ho Chi Minh City University Of Food and teachers of other universities, we are aware of the following issues of concern: 


\subsubsection{Level disparity:}

Although most schools have an entrance exam for placement, within each class and each school, the disparity is as follows:

- The difference in English proficiency between majors in the same school and between schools. For example: At the University of Natural Sciences, students of natural sciences such as Informatics, Mathematics, etc. have better English ability than students of some social majors such as Philosophy, Sociology, etc. According to the comments of the teachers of English for Specific Purposes Department at the University of Foreign Languages and Informatics in Ho Chi Minh City, the English ability of students at the University of Foreign Languages and Informatics in Ho Chi Minh City...University of Social Sciences and Humanities is better than other affiliated schools and departments. This difference is reflected in the results of the entrance exam and may be due to the characteristics of the industry that students are studying.

- There is a difference in the level of English of students from different areas of residence. This may be because the organization of English education in high schools in some localities is still limited due to a lack of teachers or a lack of qualified teachers.

\subsubsection{Student}

Most students are familiar with the traditional teaching method at the high school level but have not yet adapted to the credit-based training model. Therefore, they are quite passive, timid, and have not actively participated in classroom activities. In addition, a part of students went to English classes with a coping attitude, with the mentality of thinking that English was just a secondary subject, which affected the learning environment of the whole class.

\subsubsection{Teacher}

Challenges from teachers are reflected in such aspects as the level of teachers is not uniform, teaching methods are not uniform, especially in ESP classes, specialized knowledge of teachers is not suitable for the classroom in need of improvement. Besides, communication is also a big barrier between teachers and students in the process of teaching ESP. Most specialized teachers have little opportunity to participate in short-term and long-term training courses at home and abroad to improve their expertise and knowledge of the specialized they teach. In some schools such as the University of Science, University of Agriculture and Forestry, and the University of Pedagogy, there is a phenomenon that ESP classroom teachers are specialized teachers who have a lot of professional knowledge in sports present in English but have never been trained In foreign language teaching methods.

2.3.4. Study conditions are limited.

The main technical means of teaching in English classes today is a cassette player with a $\mathrm{CD}$, so teachers do not have the conditions to apply electronic lectures or some other software for teaching work teaching. Besides, the overcrowded class size is also one of the big challenges for teaching and learning English. For example, according to university regulations, the maximum number of students in an English class is no more than 50, but some classes at the University of Ho Chi Minh City have as many students as possible 70 .

\subsubsection{Inconsistent training goals}

- $\quad$ For teaching basic English, the majority of universities across the country now determine the output standards are not consistent, this even happens between schools with 
the same training majors. Until the beginning of the 2019-2020 school year, most of HUFI's faculties have not yet determined the English language output standards for their students.

- Until the academic year (2021), the Faculty of Foreign Languages has updated the most accurate output standards:

+ Major in English at University level: Having a foreign language certificate of at least level 5 according to the 6-level competency framework for Vietnam, requiring an equivalent/alternative output certificate for English at HUFI, TOEFL iBT 85 +, IELTS 6.5+, TOEIC $800+$ or APTIS C1.

+ Major in English at College level: Having a foreign language certificate of at least level 4 according to the 6-level competency framework for Vietnam, requiring an equivalent/alternative output certificate for English at HUFI, TOEFL iBT $85+$, IELTS 5.5+, TOEIC $600+$ or APTIS B2.

+ For non-university training majors, the output standard is also required to have a foreign language certificate of at least level 3 according to the 6-level competency framework for Vietnam, including one of TOEFL iBT 45+, IELTS 4.5+, TOEIC 450+ or APTIS B1 with a college system certifying foreign languages at least level 2 according to the 6-level competency framework TOEFL iBT 32+, IELTS 3.5+, TOEIC 400+ or APTIS A2.

Table 1: A description of foreign language output standards at some universities in three regions is given below:

\begin{tabular}{|c|c|c|}
\hline \multirow{2}{*}{ Numerical order } & School & $\begin{array}{c}\text { Benchmarks for } \\
\text { output ( English) }\end{array}$ \\
\hline 1 & Vietnam National University, Hanoi & IELTS 7.0 \\
\hline 2 & University of Social Sciences and & Faculty of Linguistics \\
\hline 3 & Humanities ( Ha Noi) & IELTS 6.0 \\
\hline 4 & Diplomatic Academy of Vietnam & TOEIC 4 skills 600+ or \\
\hline 5 & IELTS 5.5+ \\
\hline 6 & University of Da Nang - University of & TOEIC 400 \\
\hline Science and Education & TOEIC 450 \\
\hline & Yesin University & TOEIC 350-450 \\
\hline
\end{tabular}




\begin{tabular}{|c|c|c|}
\hline 7 & University Ton Duc Thang & TOEIC 500 \\
\hline 8 & Ho Chi Minh City University of \\
Technology & TOEIC 600 \\
\hline 9 & $\begin{array}{c}\text { University of Foreign Languages and } \\
\text { Informatics in Ho Chi Minh City }\end{array}$ & TOEIC \\
\hline 10 & $\begin{array}{c}\text { Viet Nam National University Ho Chi } \\
\text { Minh City, University of Social }\end{array}$ & TOEIC 4 skills 450 \\
\hline 11 & Sciences and Humanities & \\
\hline & Ho Chi Minh City University of & \\
\hline & Technology and Education & TOEIC 500 \\
\hline
\end{tabular}

(Source IIG Vietnam)

\subsubsection{For teaching English for Specific Purposes:}

Currently, the majority of English for Specific Purposes teaching materials are designed to develop the four basic skills of listening, speaking, reading, writing, and the ability to translate documents. However, there are many opinions (mostly from specialized teachers who directly teach English for Specific Purposes) of the notion that it is only necessary to supplement students with as a good deal of specialized vocabulary as possible to support professional knowledge. Many Englishes for Specific Purposes curricula are self-edited by teachers, unbalanced in the development of four skills, focusing only on reading skills and specialized vocabulary exercises. Therefore, students are not interested in learning.

In the addition, some schools have dropped English for Specific Purposes modules. In general, the current basic English and English for Specific Purposes training goals are not based on understanding and analyzing students' needs.

2.3.7. The reliability of the evaluation method is not high.

For ESP teaching at universities today, the method of assessing learning outcomes is not highly reliable when the test questions are compiled by the classroom teachers themselves. Most schools do not have an English for Specific Purposes test bank.

\subsubsection{Output}

At seminars with employers or business owners, heads of many agencies and departments complain that the quality of English used by employees or employees is too low. That led to the discussion: did ESP train meet a social need? Lack of enough? Right or wrong industry? Or will the training without information about the real needs of the society will make the training unit confused and the learners even more confused because the motivation and goals cannot be determined? 


\section{Results and Discussion}

3.1. The Real situation of students

SUMMARY TABLE OF RESULTS

Table 2: The situation of teaching and learning English for Specific Purposes Ho Chi Minh City University of Food Industry

\begin{tabular}{|c|c|c|c|c|c|c|c|c|}
\hline \multirow[b]{2}{*}{ Question } & \multicolumn{2}{|c|}{ Option A } & \multicolumn{2}{|c|}{ Option B } & \multicolumn{2}{|c|}{ Option C } & \multicolumn{2}{|c|}{ Option D } \\
\hline & $\begin{array}{c}\text { Number } \\
\text { of votes } \\
\text { to } \\
\text { choose }\end{array}$ & Ratio \% & $\begin{array}{c}\text { Number } \\
\text { of votes } \\
\text { to } \\
\text { choose }\end{array}$ & Ratio \% & $\begin{array}{c}\text { Number } \\
\text { of votes } \\
\text { to } \\
\text { choose }\end{array}$ & Ratio \% & $\begin{array}{l}\text { Number } \\
\text { of votes } \\
\text { to choose }\end{array}$ & Ratio \% \\
\hline Q1 & 0 & 0 & 0 & 0 & 100 & 100 & 0 & 0 \\
\hline Q2 & 65 & 65 & 25 & 25 & 7 & 7 & 3 & 3 \\
\hline Q3 & 5 & 5 & 55 & 55 & 25 & 25 & 15 & 15 \\
\hline Q4 & 63 & 63 & 12 & 12 & 17 & 17 & 8 & 8 \\
\hline Q5 & 34 & 34 & 25 & 25 & 31 & 31 & 10 & 10 \\
\hline Q6 & 33 & 33 & 36 & 36 & 21 & 21 & 10 & 10 \\
\hline Q7 & 12 & 12 & 55 & 55 & 13 & 13 & 20 & 20 \\
\hline Q8 & 7 & 7 & 16 & 16 & 52 & 52 & 25 & 25 \\
\hline Q9 & 31 & 31 & 33 & 33 & 24 & 24 & 12 & 12 \\
\hline Q10 & 0 & 0 & 56 & 56 & 23 & 23 & 21 & 21 \\
\hline
\end{tabular}


The fact that teaching English for Specific Purposes is not beyond the aim of completely improving the four language skills (listening, speaking, reading, and writing) for students as the cornerstone of English base can be seen in the data table above (general English). However, English for Specific Purposes is for professional, purpose-specific purposes, focusing learners' attention on the language and communication requirements in a particular area of expertise.

It can be said that the main problem of teaching English for Specific Purposes is to build students' communication skills and use specialized English texts in the field in which they are trained. In terms of training programs and goals, it is necessary to teach English for Specific Purposes of knowledge along with developing communication skills. Because, according to the training program, students have learned some basic English modules and acquired background knowledge in specialized fields through courses in their mother tongue. But through the survey of students learning English for Specific Purposes, it was found that the basic communication ability, making simple sentences of most of these students is very weak. Many classes even have more than $50 \%$ of students in a class not passing the course. A lot of you use English structure and terminology such as Vietnamese structure and the pronunciation of words, especially specialized words, are incorrect by students. This comes from many objective and subjective reasons and has been given below by the writer as some typical inadequacies:

The time for basic English courses in the first year of university is not much, not enough to build up language knowledge for students who are ready to study English for Specific Purposes due to numerous students go to university with poor English. Universities often apply general rules and set up a training program for basic English courses with only 8 credits. If students do not actively self-study outside of class hours, they will not be able to meet the language skills requirements to be able to continue studying the ESP module. Many students who take the English for Specific Purposes course still owe the basic English courses. If the debt of the basic English course is not completely resolved, it will greatly hinder the students' acquisition of knowledge and language skills in teaching the English for Specific Purposes course.

It is a fact that students in a class come from many localities inside and outside the province - most of them are from districts, communes, and rural areas with different learning conditions, so there is inevitably a diversity of qualifications. English competence and proficiency. That is not to mention the learning motivation of each student is different. Many students are not aware of the importance of English as the key to getting a job and succeeding in the future. This means that with the same content and teaching method, the level of acquisition and practice of each student in a specialized class has a big difference. Therefore, some difficulties arise in the process of teaching and learning.

On the other hand, the class size of English for Specific Purposes is too crowded, usually more than 50 students. Therefore, paying attention to the language development of teachers in class for each student is very limited. Teachers have to spend a lot of time to stabilize order, and managing and covering all students, especially students sitting at the back of the class, is a great difficulty for teachers. Therefore, many students do not have the opportunity to practice and develop language skills, especially those who are passive, shy, and self-conscious about their language knowledge. But the number of these students is usually not small due to the starting point of your circumstances and qualifications as mentioned above.

The duration for the English for Specific Purposes courses is not much, most are 2 credits (30 periods), or 3 credits ( 45 periods), only a few ESP subjects have $4-5$ credits. Providing new knowledge in parallel with practicing skills will be one-sided, especially for students 
who do not actively explore and study materials before and after class, although teachers have always tried their best to make the most of the guidance for students to self-study, practice, and practice outside of class time.

The ESP classes have minimal facilities; there are no specialist spaces, and the projector system is not completely fitted, which is critical for demonstrating activities or vocabulary majors in the class. Students will be captivated by lectures that use vibrant and realistic imagery to help them absorb ideas, insights, and memorize faster.

\subsection{Some key solutions:}

Based on the above situations and challenges, the research team proposes some key solutions to improve the teaching and the learning situation of English for Specific Purposes at HUFI and gradually improve the professionalism in training an important course for more than several thousand students of a regional university.

Training institutions step by step identify social needs to set appropriate training objectives. The authentic need of learners is that after graduation, they will use the trained ESP to do, achieve any goal in the process of career advancement. When the training process is in the right direction, the right needs will be a great stimulus for learning motivation and help the training to be more focused and targeted.

All levels of management need to agree on a general road map for the program, the number of periods, and textbooks prescribed for each specific major across the country. Each school may propose to the Ministry of Education and Training good ideas and the Ministry will agree on a common choice because that is the only way to ensure national connectivity, to serve students when they want to transfer or transfer learning.

It is necessary to clarify to learners the specific goals and requirements of this important and practical subject to gradually improve their interest and positive motivation for learning. In addition, guidance and advice on learning methods for students are equally important. Many students work very hard but do not know how to study, leading to poor results.

Training and regularly fostering English for Specific Purposes teachers through training courses on methods and capacity building. However, with the characteristics of ESP, most of the difficulty lies in specialized concepts and terms, so the sense of self-study and self-improvement of the teacher is even more important. Teachers should take the time to learn the specialized concepts and terms they are teaching. You can search on the internet or discuss with colleagues positive and interesting ESP teaching methods, even if you have to face many difficult concepts. Many teachers have good lectures that should model for other colleagues to learn and so on, the experience will be accumulated more and more.

One of the most critical skills for teachers in developing instructional materials. The training units must collaborate to agree on the collection of regular, revised, and updated textbooks new training requires, with the assistance of international organizations, sample documents on ESP, or the support of the Ministry's general professional council. Any major's ESP will be measured and used uniformly around the country for that major. It will be simpler and more convenient to communicate and pass credits between training units this way. The annual conference to develop teaching methods and materials would provide a better foundation for debate on that basis.

Build a bank of exam questions using TOEIC or other international standards as a foundation. Students must be prepared according to this requirement while preparing to 
prepare for the final exam. Based on the training institution's resources, it is important to promote the use of exam forms similar to international exams to boost learning motivation and tailor teaching activities to students' communication abilities. The problem-solving committee must be compensated commensurate with the effort they invest, to encourage faculty members to participate in standards-based topics. Subject teachers must be trained, trained and must be people with practical experience in teaching English for Specific Purposes.

In addition to general skills such as listening, speaking, reading and writing, grammar... students need to be trained in additional soft skills such as interpreting, summarizing, inferring, questioning skills Topics, expressions, comparisons, contrasts, presentations, group work, report writing... It is the self-study skills and active learning activities that help students absorb teachers need to improve their ability to learn professional skills by learning or self-studying, training... - Training institutions at each university should create conditions to have multi-purpose classrooms for students during foreign language lessons. A projector is the most minimal means of modern teaching, active teaching because, in that environment, both teachers and students promote positivity in their fields. Equipped with the internet in the classroom is even more ideal when teachers and students can look up issues related to terminology or concepts online... The ideal ESP class should not exceed 30 students. Currently, this is not too difficult to do because students choose credits to accumulate and if they study well with the quality they are willing to pay higher tuition fees for "attractive" credits.

\section{Conclusions}

We hope that in the shortest possible time, it will be sufficient to resolve the ESP teaching-learning situation and to jointly solve a portion of the individual difficulties, so that synchronous change is not out of control.

In short, creating a learner-centered ESP preparation roadmap that addresses societal needs is a great idea. In the current trend, the entire society is interested in improving the standard of teaching capacity to serve Vietnam's promising education industry. The organization of ESP training according to social needs, as stated, would help save a lot of money and effort for training units while also creating for society human resources with high professional qualifications, fluent in foreign languages to keep pace with modernization and globalization.

\section{Patents}

Funding: Please add: This research received no external funding.

Conflicts of Interest: The authors declare no conflict of interest.

\section{Appendix}

Survey Question for investigating English prepositions uses

Question 1: Do you study English in specialized in?
$\begin{array}{lll}\text { a. } 1 & \text { b. } 2 & \text { c. } 3\end{array}$
d. 4

Question 2: As you are learning English.

a. Essential b. Necessary c. No need to d. Completely unnecessary.

Question 3: You learn English major to do? 
a. Required to learn b. Service work c. Study says d. Other purposes

Question 4: Structure of specialized English programs that you are attending:

a. Theory $30 \%$ - $70 \%$ practice

b. Theory $45 \%-55 \%$ practice

c. Theory $50 \%-50 \%$ practice

d. Alternatives

Question 5: Do you feel that learning English subjects is like?

a. Difficult

b. Difficult

c. Normal

d. Easy Question

6: The difficulties you face in learning English are what subjects?

a. Lack of textbooks

b. Little opportunity to communicate

c. Practice at least

d. Lack of vocabulary

Question 7: Teachers are often held practices like?

a. Personal

b. Pairs

c. Group

d. The class Otherwise

Question 8: Do you use How much time for learning English majors in one day?
a. 30 minutes
b. 30 minutes - 1 hour
c. From 1 hour - 2 hours
d. Alternatives

Question 9: Do you feel he specialized in the field of sound?

a. Very useful 

b. Useful
c. Not useful
d. Waste of time

Question 10: Facilities for English learning school subjects do you have?

a. Only normal lecture

b. There are audio-visual equipment

c. Audio-visual room

d. There are foreign language classrooms

\section{References}

Tar, Varga and Wiwezaroski. (2009). Improving ESP Teaching through Collaboration: The Situation in Hungary. ESP World. ESP World, volume 8.

Bekir Savas. (2009). Role of Functional Academic Literacy in ESP teaching: ESP Teacher Training in Turkey for Sustainable Development. The Journal of International Social Research, Volume 2/9.

Bouzidi. (2009). Between the ESP Classroom and the Workplace: Bridging the Gap. English Teaching Forum, Number 3.

Chuân đầu ra Ngoại ngũu HUFI cập nhật 2020-2021. (2021, 03 24). Retrieved from https://knn.hufi.edu.vn/chuan-dau-ra/chuan-dau-ra-ngoai-ngu-hufi-cap-nhat-2020-2021

Kaur and Clarke. (2009). Analyzing the English Language Development of Human. English for Specific Purposes, Issue 3 (24), Volume 8.

Kaur and Clarke. (2009). Analyzing the English Language Development of Human. English for Specific Purposes, Issue 3 (24), Volume 8.

Marginson and Mc.Burnie. (2004). Cross-border post-secondary education in the Asia Pacific region. In for OECD, Internationalisation and Trade in Higher Education (pp. 137-204). Paris: OECD.

Nghi, T. T. (2013). THE THEORETICAL STUDY FOR IMPLEMENTING CBI IN TEACHING ESP IN VIETNAM. Science Journal of Food Science and Technology, 31.

Tar, Varga and Wiwezaroski. (2009). Impoving ESP Teaching through Collaboration: The Situation in Hungary. ESP World. ESP World, volume 8.

Tavakoli, A. a. (2009). Reassessing the ESP Courses Offered to Engineering Students in Iran. English for Specific Purposes, Volume 8(Issue 23), Issue 23, Volume 8. 